\title{
Changes in energetic metabolism of Biomphalaria glabrata (Mollusca, Planorbidae) in response to exogenous calcium
}

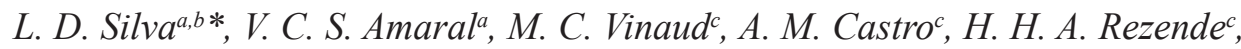 \\ D. B. Santos ${ }^{c}$, C. C. Mello-Silva ${ }^{d}$ and J. C. B. Bezerra ${ }^{c}$ \\ ${ }^{a}$ Ciências Exatas e Tecnológicas - CCET, Universidade Estadual de Goiás - UEG, Câmpus Anápolis, BR 153, 3105 , \\ CEP 75132-903, Anápolis, GO, Brazil

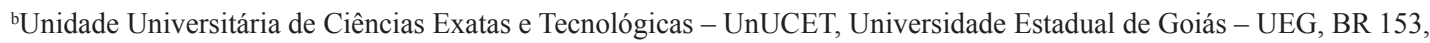 \\ 3105 CEP 75132-903, Anápolis, GO, Brazil \\ 'Laboratório de Estudos da Relação Parasito-Hospedeiro, Instituto de Patologia Tropical e Saúde Pública - IPTSP, \\ Universidade Federal de Goiás - UFG, Rua 235, s/n, Setor Universitário, CEP 74650-050, Goiânia, GO, Brazil \\ dLaboratório de Avaliação e Promoção da Saúde Ambiental, Instituto Oswaldo Cruz, Fundação Oswaldo Cruz - \\ FIOCRUZ, Avenida Brasil, 4365, Manguinhos, CEP 21040-360, Rio de Janeiro, RJ, Brazil \\ *e-mail: luciana.silva@ueg.br
}

Received: August 26, 2015 - Accepted: December 21, 2015 - Distributed: May 31, 2017

(With 4 figures)

\begin{abstract}
Calcium is considered an essential element for the metabolism of aquatic snail Biomphalaria glabrata (Say, 1818), intermediate host of Schistosoma mansoni Sambon, 1907 in Brazil, and represents a limiting factor to its distribution and adaptation to the environment. This study investigated the effect of different concentrations of exogenous $\mathrm{CaCO}_{3}$ on the energetic metabolism of B. glabrata for better understanding the physiological interference of chemical elements dissolved in the environment with the physiology of this species. Sixty-day-old snails were distributed into six groups, five exposed to different concentrations of $\mathrm{CaCO}_{3}(20,40,60,80$ and $100 \mathrm{mg} / \mathrm{L})$ and a control group. The exposure to $\mathrm{CaCO}_{3}$ was assessed over time, with analysis of 15 snails of each group in the following intervals: 1, 14, 21 or 30 days for hemolymph extraction. Concentrations of calcium and glucose in the hemolymph were determined by commercial kits, and organic acids were extracted using an ion exchange column and analyzed by high-performance liquid chromatography. Concentration of calcium in the hemolymph showed no significant difference $(p>0.05)$ from the control group and between the concentrations tested. Concentration of glucose decreased $(\mathrm{p}<0.05)$ in the treatments of exposure to 20 and $40 \mathrm{mg} / \mathrm{L}$ and increased when exposed to 80 and $100 \mathrm{mg} / \mathrm{L} \mathrm{CaCO}_{3}$ compared to control and to other concentrations tested over 30 days. The organic acids pyruvate, oxaloacetate, citrate, succinate, fumarate, beta-hydroxybutyrate and lactate presented increased concentrations, while propionate and acetoacetate, decreased concentrations, when exposed to $\mathrm{CaCO}_{3}$ compared to control. Considering the influence of different periods of exposure to $\mathrm{CaCO}_{3}$, on the $14^{\text {th }}$ day, there were stronger alterations in the metabolism of B. glabrata. In conclusion, exposure to $\mathrm{CaCO}_{3}$ reduced the concentration of glucose, which is metabolized into pyruvate, the final product of glycolysis, and also influenced the energetic metabolism pathways, indicating an aerobic or partially anaerobic functioning.
\end{abstract}

Keywords: snails, Krebs cycle, $\mathrm{CaCO}_{3}$ exposure, energetic metabolism.

\section{Alterações no metabolismo energético de Biomphalaria glabrata em resposta ao cálcio exógeno}

\section{Resumo}

O cálcio é considerado um elemento essencial no metabolismo do molusco aquático Biomphalaria glabrata (Say, 1818), principal hospedeiro intermediário de Schistosoma mansoni Sambon, 1907 no Brasil e, tem sido descrito como um fator limitante na distribuição e adaptação desse molusco no ambiente. O presente trabalho avaliou o efeito de diferentes concentrações de carbonato de cálcio $\left(\mathrm{CaCO}_{3}\right)$ exógeno ao metabolismo energético de B. glabrata, a fim de subsidiar uma melhor compreensão da interferência de elementos químicos dissolvidos no meio aquático na fisiologia destes moluscos. Foram utilizados moluscos com sessenta dias de vida, distribuídos em seis grupos, cinco expostos a diferentes concentrações de $\mathrm{CaCO}_{3}(20,40,60,80$ e $100 \mathrm{mg} / \mathrm{L})$ e um controle. A exposição ao $\mathrm{CaCO}_{3}$ foi avaliada em função do tempo, sendo retirados 15 moluscos de cada grupo nos seguintes intervalos: 1, 14, 21 ou 30 dias para extração da hemolinfa. As concentrações de cálcio e glicose na hemolinfa foram determinadas usando-se kits comercial e os ácidos orgânicos foram extraídos por meio da coluna de troca iônica e analisados através cromatografia líquida 
de alta eficiência. Os resultados demonstraram que a concentração de cálcio na hemolinfa não apresentou diferença significativa $(p>0,05)$ em relação ao controle e nas concentrações testadas. A concentração de glicose diminuiu $(p<0,05)$ nas exposições a $20 \mathrm{mg}$ e $40 \mathrm{mg} / \mathrm{L}$ e aumentou nas exposições a $80 \mathrm{mg}$ e $100 \mathrm{mg} / \mathrm{L}$ de $\mathrm{CaCO}_{3}$ em relação ao controle e demais concentrações testadas ao longo de 30 dias. Os ácidos orgânicos piruvato, oxaloaceato, citrato, succinato, fumarato, $\beta$-hidroxibutirato e lactato tiveram suas concentrações aumentadas, enqunato, propionato e acetoacetato tiveram suas concentrações diminuídas na exposição ao $\mathrm{CaCO}_{3}$ comparada ao controle. Quanto a influência dos diferentes períodos de exposição ao $\mathrm{CaCO}_{3}$, aos 14 dias, as alterações no metabolismo de $B$. glabrata foram mais expressivas. Conclui-se que as exposições ao $\mathrm{CaCO}_{3}$ influenciaram na redução de glicose, sendo esta metabolizada a piruvato, produto final da glicólise e alteraram as vias de metabolismo energético, indicando um funcionamento aeróbio ou parcialmente anaeróbio.

Palavas-chave: moluscos, ciclo de Krebs, exposição ao $\mathrm{CaCO}_{3}$, metabolismo energético.

\section{Introduction}

Biomphalaria glabrata (Say, 1818), the main intermediate host of Schistosoma mansoni Sambon, 1907 in Brazil, is a model for ecologic, toxicological and parasitological studies, since it occupies a high trophic level and is a food resource for several organisms (Barbosa and Barbosa, 1994; Paraense, 1970). Snails are good bioindicators of contamination of freshwater environments (Cantinha et al., 2010; Carvalho et al., 1988), as they are sensitive to environmental alterations, such as chemical elements dissolved in the water, hydrography, soil composition, climate and physical geography (Abílio et al., 2007; Guerino et al., 2009). Chemical elements such as calcium, copper, iron, zinc and manganese are essential to the metabolism of such organisms (Barbosa and Barbosa, 1994).

Amongst the chemical elements analyzed in Biomphalaria, calcium is one of the most studied, both in conditions of natural environment (Rosas, 1987; Silva and Barros, 2001) and in laboratory (Davies and Erasmus, 1984; Tunholi-Alves et al., 2012). Calcium has been shown to participate in shell formation (Marxen et al., 2003), muscle contraction (Bielefeld et al., 1992), embryo development, growth, resistance to predators (Davies and Erasmus, 1984) and in immunological responses (Zelck et al., 1995). It is also important as a cofactor for enzymes involved in glycolysis and tricarboxylic acid (TCA) cycle pathways (Becker, 1980; Tunholi et al., 2011) and as a component of buffer solutions.

For energy production, B. glabrata uses the glucose available in the hemolymph or that stored as glycogen in organs, such as digestive gland and in the cephalopodal mass (Schwartz and Carter, 1982). Under physiological stress, such as estivation, parasitic infections or exposure to molluscicides, the snails use sources alternative to glucose, like lipids and proteins (Mello-Silva et al., 2010; Tunholi et al., 2013).

Organic acids, produced during glycolysis and gluconeogenesis, are important since alterations in their production influence the intermediate metabolic pathway used by $B$. glabrata. In aerobic conditions, it is possible to observe high concentrations of pyruvate, oxaloacetate, citrate, succinate, fumarate and malate in the snail hemolymph, which indicate the activation of the TCA cycle. In an alternative metabolic pathway, it is possible to find increased concentrations of ketone bodies, such as acetoacetate and beta-hydroxybutyrate, which are products of the lipid metabolism, while the increase in lactate, oxalate and propionate indicate anaerobic glycolytic processes (Bezerra et al., 1999; Tunholi et al., 2013).

This study intends to provide a better understanding of the energetic metabolism in B. glabrata. The comprehension of the snail metabolism in an environment rich in calcium will support the development of better molluscicides, which will work well in aquatic environments rich in this element and aid in the control of the host of schistosomiasis.

\section{Methods}

\subsection{Maintenance of Biomphalaria snails}

In this study, B. glabrata snails, BH strain, were provided by the Experimental Schistosomiasis Laboratory, Oswaldo Cruz Foundation, Rio de Janeiro, Brazil. Animals were maintained in the Malacology Laboratory, Tropical Pathology and Public Health Institute (IPTSP), of Federal University of Goiás (UFG), in polyethylene tanks containing dechlorinated water with neutral to alkaline $\mathrm{pH}$, and temperature ranging from $23^{\circ} \mathrm{C}$ to $25^{\circ} \mathrm{C}$. The tanks were daily monitored and cleaned once a week. The snails were fed ad libitum with fresh lettuce leaves (Lactuca sativa L.), previously washed with dechlorinated water.

\subsection{Composition of the study group and hemolymph extraction}

In this study, 420 snails with shell diameter ranging from 8 to $10 \mathrm{~mm}$ were divided into six groups of 70 animals each. Snails were taken randomly from the maintenance aquaria and reassigned to properly identified plastic boxes. In the test groups, $20,40,60,80$ or $100 \mathrm{mg} / \mathrm{L}$ calcium carbonate were diluted in dechlorinated water. The control group did not receive calcium carbonate in the water. At the intervals of 1, 14, 21 or 30 days, the hemolymph was collected from 15 snails (pool of five snails each, resulting in three samples) of each experimental group, according to Bezerra et al. (1999). The boxes had the water and calcium carbonate concentrations renewed weekly.

\section{3. $\mathrm{pH}$ measurement}

The $\mathrm{pH}$ of hemolymph was measured using $\mathrm{pH}$ indicator strips (pH 0-14, Merck $^{\circledR}$ ). The digital $\mathrm{pH}$ meter PHS-3B Phtek was used to measure the $\mathrm{pH}$ of the dechlorinated water. 


\subsection{Organic acid profile}

Hemolymph was centrifuged $\left(120 \mathrm{~g} / 5 \mathrm{~min}, 2^{\circ} \mathrm{C}\right)$ to separate the serum from the hemocytes and tissue particles. From the serum, organic acids were extracted by an ion exchange chromatographic column (Bond Elut ${ }^{\circledR}$ - Varian). Using a vacuum pump, this column was activated by $1 \mathrm{~mL}$ of HCL $(0.5 \mathrm{~mol} / \mathrm{L}), 1 \mathrm{~mL}$ methanol and $2 \mathrm{~mL}$ of ultrapure water. Then, $250 \mu \mathrm{L}$ hemolymph was applied to the column. After application of the sample, $2 \mathrm{~mL}$ of ultrapure water was added, the Bond Elut was removed from vacuum, $250 \mu \mathrm{L} 0.5 \mathrm{M} \mathrm{H}_{2} \mathrm{SO}_{4}$ was added, and the mixture was centrifuged at $500 \mathrm{~g} / 5$ minutes, $2{ }^{\circ} \mathrm{C}$ (Bezerra et al., 1999).

The resulting sample was subjected to high performance liquid chromatography (HPLC - Varian ProStar) with an exclusion column (BIORAD-Aminex ion exclusion HPX $-87 \mathrm{H}, 300 \times 7.8 \mathrm{~mm}$ ). A pre-column (BIORAD-Aminex HPX - 85) protects the separation column. The eluent used in the mobile phase was the sulfuric acid $(5 \mathrm{mmol} / \mathrm{L})$ at room temperature with $0.6 \mathrm{~mL} /$ minute flow, attached to an UV-visible light detector at a wavelength of $210 \mathrm{~nm}$. Each sample injected contained $50 \mu \mathrm{L}$ volume.

The retention time of the organic acids and the peak area of the substances were calculated by ProStar Varian ${ }^{\circledR}$ software providing their concentrations in the sample. Organic acids were identified accordingly to their retention time and to the calibration previously performed in HPLC (Bezerra et al., 1999).

\subsection{Calcium and glucose concentrations in the hemolymph}

Concentrations of calcium and glucose in the hemolymph were determined by commercial kits (Liquiform LABTEST $^{\circledR}$ kit) and the results were expressed as mg of calcium or glucose/dL of hemolymph. The reading was made by a BIOPLUS ${ }^{\circledR}$ spectrophotometer (BIO 2000 ${ }^{\circ}$ ), at $545 \mathrm{~nm}$.

\subsection{Statistical analysis}

Data were analyzed by two-way ANOVA (factor 1: concentration of $\mathrm{CaCO}_{3}$; factor 2: days of exposure). Whenever indicated by significant F-values, group differences were identified by Duncan's test. A P-value of 0.05 or less was considered significant.

\section{Results}

$\mathrm{pH}$ values of the solutions with $20,40,60,80$ and $100 \mathrm{mg}$ $\mathrm{CaCO}_{3}$ were analyzed. These solutions presented $\mathrm{pH} 8.5$ in $20 \mathrm{mg}, 9.0$ in the other concentrations of $\mathrm{CaCO}_{3}$ and 8.0 in the control water. $\mathrm{pH}$ values in the hemolymph of snails exposed to different concentrations of $\mathrm{CaCO}_{3}$ was 8.0 when exposed to all concentrations; however, the $\mathrm{pH}$ of the control group was 7.0.

Figure 1 illustrates the substrates of the energetic metabolic pathways detected in the hemolymph of B. glabrata

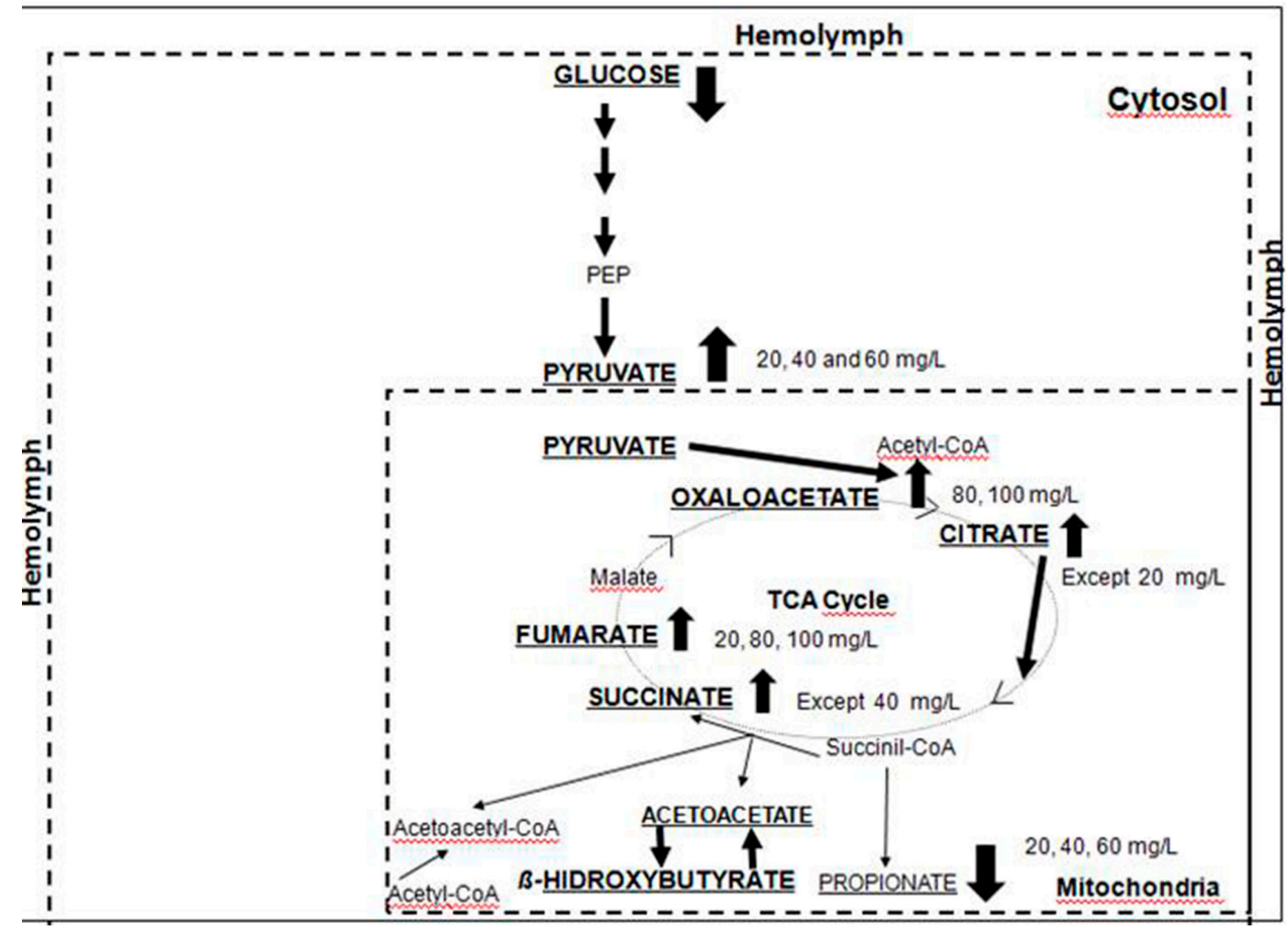

Figure 1. Schematic representation of the substrates used in metabolic pathways for energy production in Biomphalaria glabrata (Say, 1818) exposed to $\mathrm{CaCO}_{3}$ for 30 days, in relation to the control group. The underlined substances were analyzed in this study, the bold substances were increased. The substances not bolded decreased. 
exposed to $\mathrm{CaCO}_{3}$ compared to the control group during a period of thirty days of exposure.

The results presented in Figure 2A, B show the presence of calcium and glucose in the hemolymph of snails exposed to different concentrations of $\mathrm{CaCO}_{3}$. Two-way ANOVA revealed no significant differences $\left[\mathrm{F}_{(15.48)}=1.156\right.$; $p>0.3365]$ regarding the secretion/excretion of calcium due to the exposure to different concentrations of $\mathrm{CaCO}_{3}$ in different time intervals. However, there were significant differences between groups $\left[\mathrm{F}_{(15,48)}=340.64 ; p<0.0001\right]$ regarding the secretion/excretion of glucose by B. glabrata. The post-hoc test evidenced a significant reduction in glucose concentration in the hemolymph of snails exposed to 20 and $40 \mathrm{mg} \mathrm{CaCO}_{3}$ for thirty days in relation to the control group and the other concentrations tested.

Significant differences were found in the concentrations of organic acids, such as pyruvate and lactate (Figure 2C, D), oxaloacetate and citrate (Figure 3A, B), succinate and fumarate (Figure 3C, D), acetoacetate and beta-hydroxybutyrate (Figure 4A, B) and propionate (Figure 4C). There was an increase in the concentrations of pyruvate $\left[\mathrm{F}_{(15,48)}=122.91\right.$; $p<0.0001]$, oxaloacetate $\left[\mathrm{F}_{(15.48)}=237.12 ; p<0.0001\right]$, citrate $\left[\mathrm{F}_{(15,48)}=364.41 ; p<0.0001\right]$, succinate $\left[\mathrm{F}_{(15,48)}=38.11\right.$; $p<0.0001]$, fumarate $\left[\mathrm{F}_{(15,48)}=113.66 ; p<0.0001\right]$, beta-hydroxybutyrate $\left[\mathrm{F}_{(15,48)}=153.15 ; p<0.0001\right]$ and lactate $\left[\mathrm{F}_{(15,48)}=96.17 ; p<0.0001\right]$. There was also a decrease in the propionate $\left[\mathrm{F}_{(15,48)}=153.73 ; p<0.0001\right)$ and acetoacetate concentrations $\left[\mathrm{F}_{(15,48)}=65,45 ; p<0.0001\right]$ during the period in which the snails were exposed to $\mathrm{CaCO}_{3}$ in relation to the control group.

The concentrations of organic acids varied between the test groups: $20 \mathrm{mg} \times 40 \mathrm{mg}, 60 \mathrm{mg}, 80 \mathrm{mg}, 100 \mathrm{mg}$; $40 \mathrm{mg} \times 60 \mathrm{mg}, 80 \mathrm{mg}, 100 \mathrm{mg} ; 60 \mathrm{mg} \times 80 \mathrm{mg}, 100 \mathrm{mg}$ and $80 \mathrm{mg} \times 100 \mathrm{mg}$ of $\mathrm{CaCO}_{3}$. The concentrations of pyruvate, citrate, fumarate, propionate, beta-hydroxybutyrate and lactate decreased after one day of exposure to $20 \mathrm{mg}$ of $\mathrm{CaCO}_{3}$ and increased after fourteen days. The oxaloacetate concentration increased after one day exposure to $20 \mathrm{mg} \mathrm{CaCO}_{3}$ and decreased after fourteen days. There was a decrease in succinate concentration after one day exposure to $20 \mathrm{mg}$ $\mathrm{CaCO}_{3}$ and an increase after thirty days when compared to the other $\mathrm{CaCO}_{3}$ concentrations. In addition, there was an increase in acetoacetate concentrations after fourteen days of exposure to 20 and $40 \mathrm{mg} \mathrm{CaCO}_{3}$ and a decrease after twenty-one days when compared to the other $\mathrm{CaCO}_{3}$ concentrations.
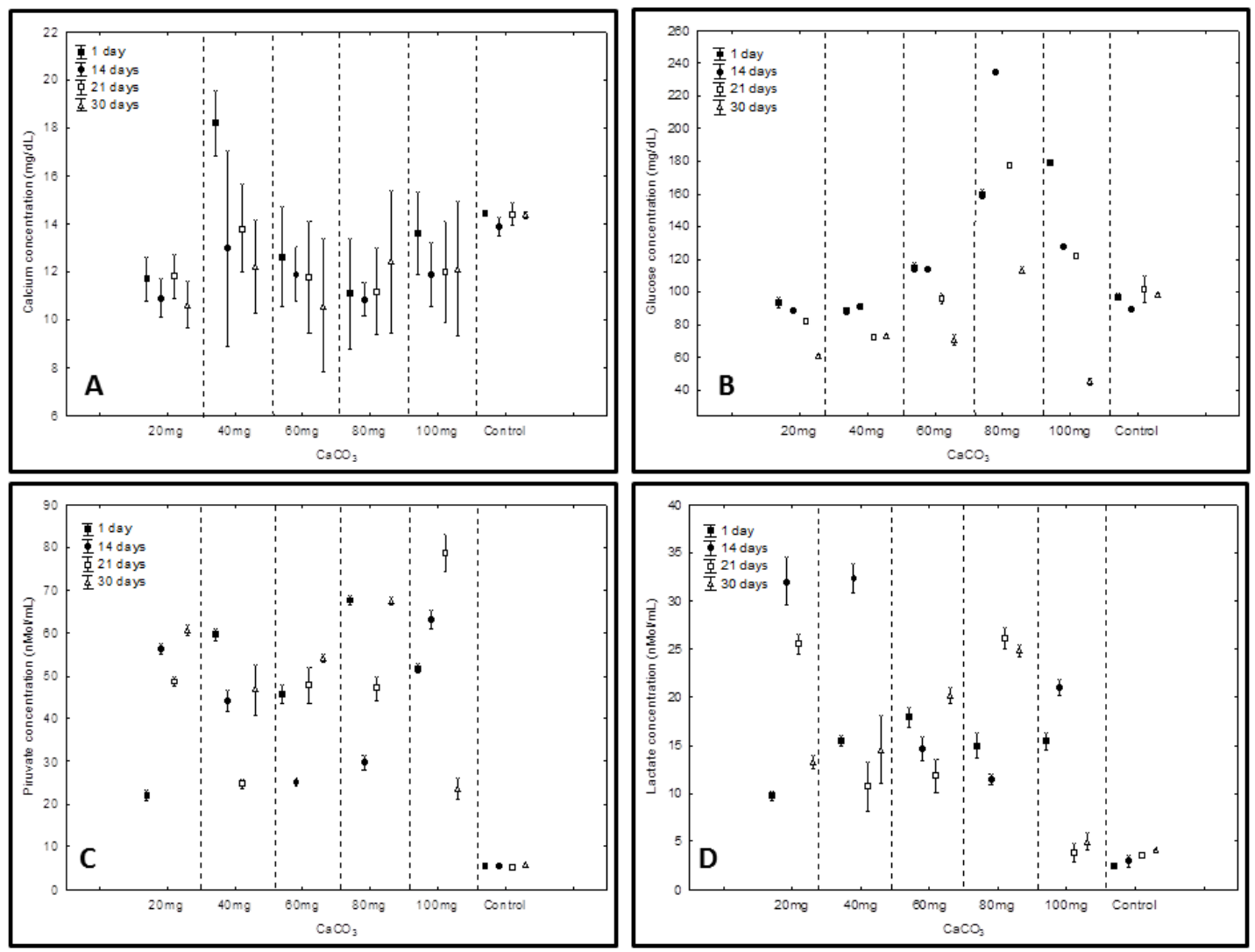

Figure 2. Mean concentrations of calcium (A); glucose (B); pyruvate (C) and lactate (D) in the hemolymph of Biomphalaria glabrata (Say, 1818) exposed to different $\mathrm{CaCO}_{3}$ concentrations $(20 \mathrm{mg}, 40 \mathrm{mg}, 60 \mathrm{mg}, 80 \mathrm{mg}$ and $100 \mathrm{mg} / \mathrm{L}) \mathrm{during}$ different time intervals (1, 14, 21 and 30 days). 

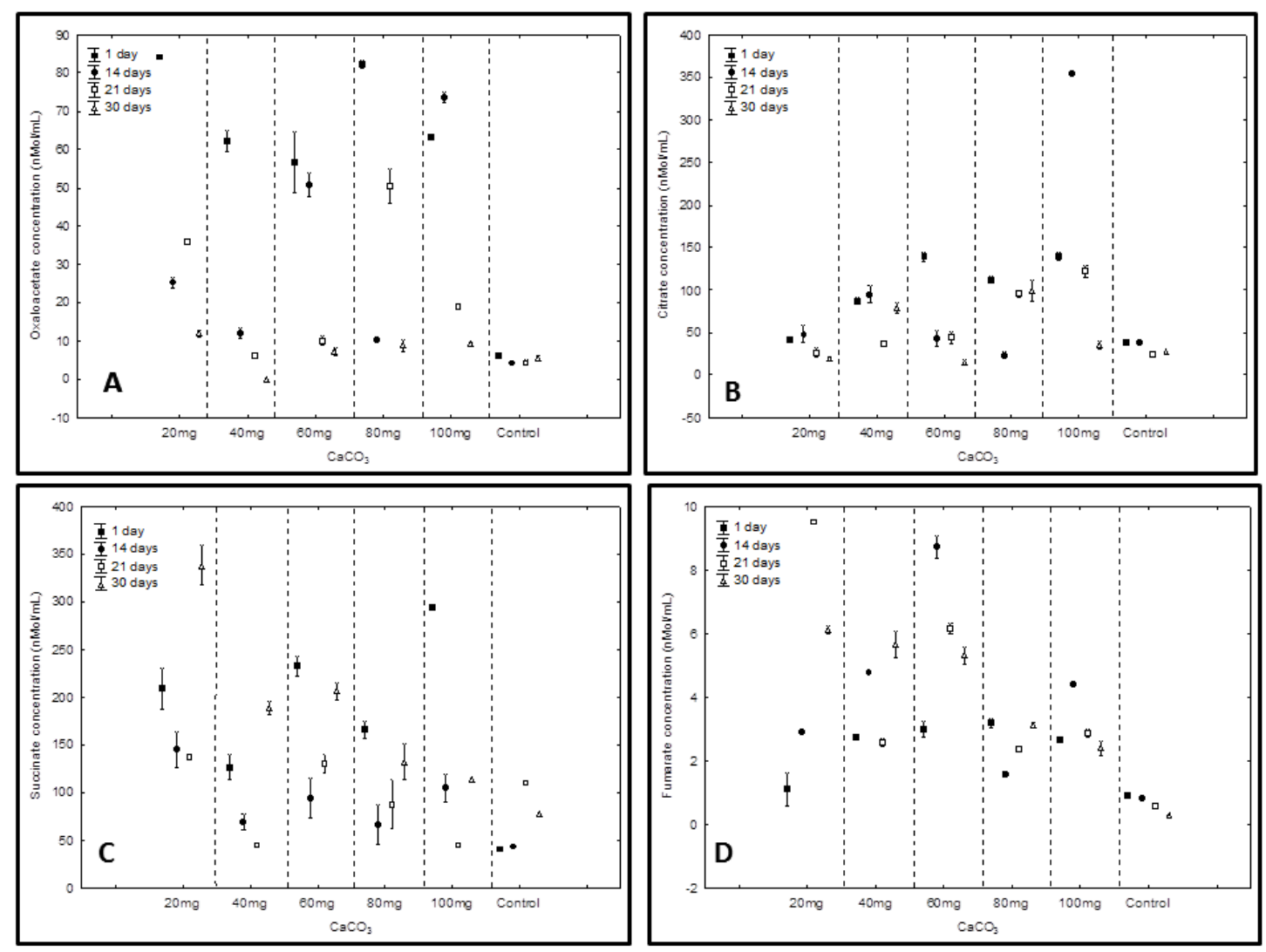

Figure 3. Mean concentrations of oxaloacetate (A); citrate (B); succinate (C) and fumarate (D) in the hemolymph of Biomphalaria glabrata (Say, 1818) exposed to different $\mathrm{CaCO}_{3}$ concentrations (20 mg, $40 \mathrm{mg}, 60 \mathrm{mg}, 80 \mathrm{mg}$ and $100 \mathrm{mg} / \mathrm{L}$ ) during different time intervals $(1,14,21$ and 30 days).

\section{Discussion}

The maintenance of homeostasis in the population of B. glabrata snails and the alkalinity of the environment depend on the presence of calcium, resulting from the dissociation of $\mathrm{CaCO}_{3}$ (Lewis et al., 2007). In nature, there is a chemical balance between the fixation and the solubilization of metallic complexes and this equilibrium can be altered by environmental variations in salinity, $\mathrm{pH}$, temperature and hydrodynamics (Silva et al., 2010). The exogenous calcium in this study interfered directly with the $\mathrm{pH}$ of the hemolymph, indicating the importance of this element to the snail. Furthermore, other studies demonstrated that high concentrations of calcium in the environment are important for B. glabrata development, since it was observed that the snail prefers to colonize calcium-rich habitats (Silva et al., 2006).

$\mathrm{Ca}^{2+}$ and $\mathrm{HCO}_{3}^{-}$are absorbed by cells of the intestinal epithelium of aquatic snails. The reaction catalyzed by carbonic anhydrase under hydrated $\mathrm{CO}_{2}$ results in the production of $\mathrm{H}^{+}$and $\mathrm{HCO}^{-}$. Ions $\mathrm{H}^{+}$are excreted by the hydrogen pumps that create a negative electric gradient that permits the influx of $\mathrm{Ca}^{2+}$ through voltage dependent channels. Thus, the $\mathrm{H}^{+}$excretion facilitates the activity of $2 \mathrm{H}^{+} / 1 \mathrm{Ca}^{2+}$ exchanger (Ebanks et al., 2010).

In our study, the exposure of B. glabrata to different concentrations of $\mathrm{CaCO}_{3}$ caused no change in $\mathrm{Ca}^{2+}$ concentration in the hemolymph, which suggests that this ion was transported via hemolymph to different reservoirs. Some of the possible reservoirs could be the shell (Marxen et al., 2003), the calcium cells present in the connective tissue of the snail (Davies and Erasmus, 1984), or it could be stored in the form of pearls in the digestive gland or intestine (Magalhães et al., 2011a). For this reason, the described increase in $\mathrm{Ca}^{2+}$ in B. glabrata hemolymph when exposed to $20 \mathrm{mg} / \mathrm{L} \mathrm{CaCO}_{3}$ for fifteen days could be explained by the mobilization of this ion from the shell to the hemolymph to work as a buffering agent (Becker, 1980).

The $\mathrm{Ca}^{2+}$ is also important in the glycolytic and TCA metabolic pathways of pulmonate aquatic snails, as it acts as a cofactor in the activation of many enzymes (Tunholi et al., 2013; Sminia et al., 1980). Our findings indicate a reduction in the concentration of glucose in the hemolymph of snails exposed to 20 and $40 \mathrm{mg}$ of $\mathrm{CaCO}_{3}$. The results showed a production of pyruvate from glucose, which might indicate the glycolytic pathway. Other studies demonstrated a partial 

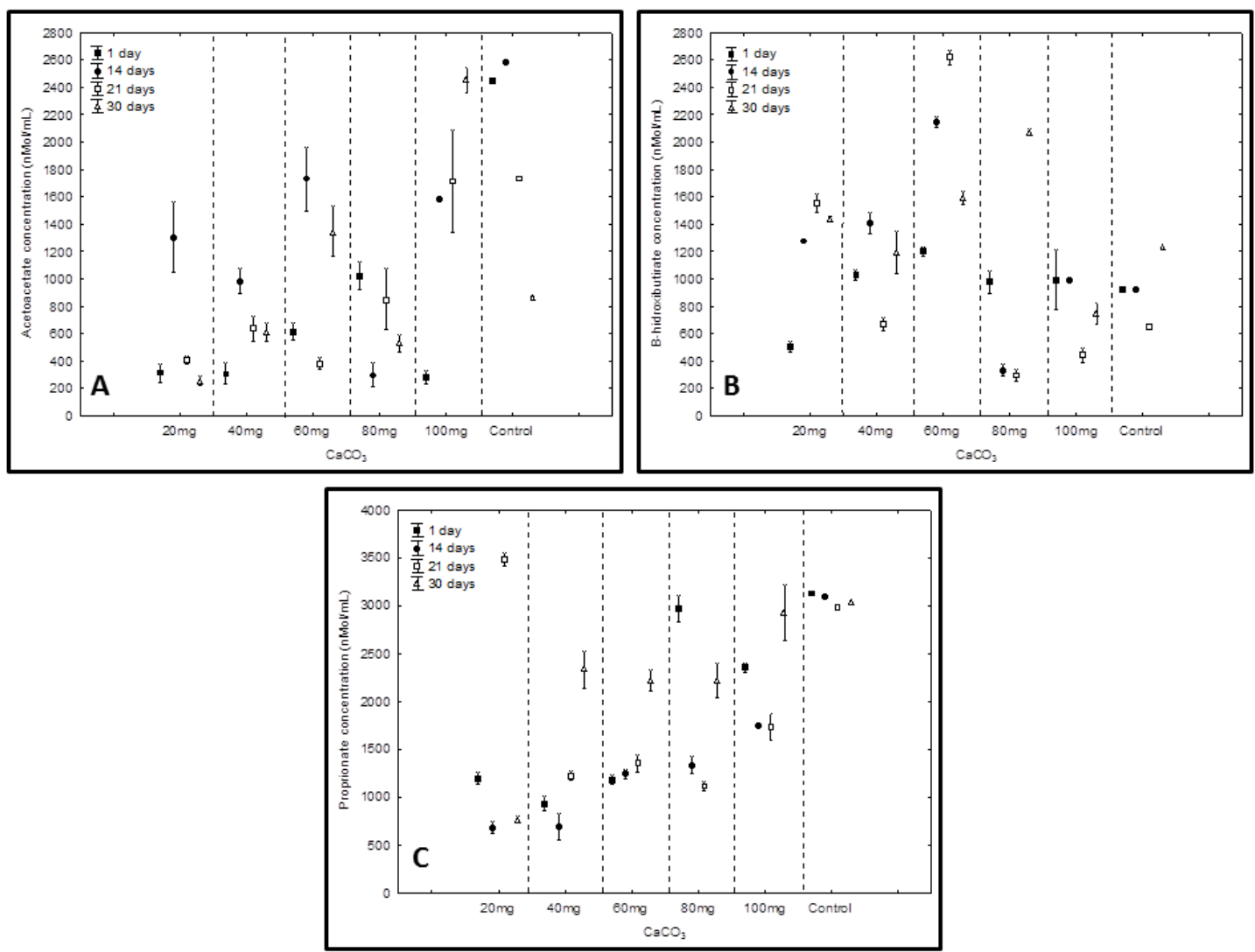

Figure 4. Mean concentrations of acetoacetate (A); B-hidroxibutirate (B) andpropionate (C) in the hemolymph of Biomphalaria glabrata (Say, 1818) exposed to different $\mathrm{CaCO}_{3}$ concentrations $(20 \mathrm{mg}, 40 \mathrm{mg}, 60 \mathrm{mg}, 80 \mathrm{mg}$ and $100 \mathrm{mg} / \mathrm{L}$ ) during different time intervals $(1,14,21$ and 30 days).

reversal of the TCA cycle in B. glabrata, when malate and fumarate produced could then be converted into succinate (Hochachka, 1983). In this study, it was not possible to detect malate; this might suggest that this organic acid was reduced to fumarate by the enzyme fumarate reductase (Bezerra et al., 1997). Fumarate would then be metabolized into succinate and then converted into propionate for the production of energy and the maintenance of the redox balance. This condition has been observed in studies on the metabolism in B. glabrata infected with S. mansoni (Tielens, 1994). The hemolymph of the snails exposed to different concentrations of $\mathrm{CaCO}_{3}$ presented a decreased concentration of propionate and an increased concentration of succinate. This could indicate that succinate was not converted into propionate but was secreted/excreted as a product of the reversal of the TCA cycle.

When the snails were exposed to calcium for thirty days, there was an increase in beta-hydroxybutyrate concentration and decrease in acetoacetate in the hemolymph, which could suggest that acetoacetate was reduced by beta-hydroxybutyrate dehydrogenase enzyme and this indicates an alternative metabolic pathway for energy production. In corroboration with this result, it was observed an increase in the concentration of citrate in the hemolymph of snails exposed to 40 and $60 \mathrm{mg} \mathrm{CaCO}_{3}$ for one and thirty days when compared to the control group. The increased concentration of citrate may be the result of the acetyl-CoA conversion into citrate, as acetyl-CoA is a product of beta-hydroxybutyrate oxidation (Meyer et al., 1986). The enzymatic activity of beta-hydroxybutyrate dehydrogenase was also demonstrated in B. glabrata by the alterations verified in the TCA cycle (Bailey and Horne, 1972). Stanislawski and Becker (1979) reported a decrease in acetoacetate and beta-hydroxybutyrate concentrations in conditions of starvation and an increase in those acids when B. glabrata was infected with $S$. mansoni. These authors suggest that the presence of the parasite in the snail stimulates ketogenesis. This may indicate that ketone bodies are involved in the development of infection in the snail. Nevertheless, it is important to highlight the scarce literature regarding ketone bodies in snails. Also, the exposure to different concentrations of $\mathrm{CaCO}_{3}$ resulted in an increase in lactate in the hemolymph. Our results suggest that, at first, the metabolism was aerobic, but as the concentration of $\mathrm{CaCO}_{3}$ increased, the metabolism shifted to anaerobic. The reduced concentrations of propionate found in this study suggest its role as substrate for succinate production (Hochachka, 1983). Augusto et al. (2012) demonstrated the 
importance of calcium in the maintenance of the life cycle of $S$. mansoni, pointing out that calcium is important for the survival of infected snails and that the concentration of calcium is also related to the emergence of cercariae.

In conclusion, exposure of snails to $\mathrm{CaCO}_{3}$ altered the catabolism of glucose into pyruvate and changed the profile of organic acids in the hemolymph of B. glabrata. This suggests that these animals underwent physiological adjustments in the evaluated periods. In addition, the increase in the concentrations of oxaloacetate, citrate, succinate and fumarate may indicate an aerobic or partially anaerobic functioning of the metabolism.

\section{References}

ABÍLIO, F.J.P., RUFFO, T.L.M., SOUZA, A.H.F.F., FLORENTIN, H.S., OLIVEIRA JUNIOR, E.T.O., MEIRELES, B.N. and SANTANA, A.C.D., 2007. Macroinvertebrados bentônicos como bioindicadores de qualidade ambiental de corpos aquáticos da caatinga. Oecologia Brasiliensis, vol. 11, no. 03, pp. 397-409. http://dx.doi.org/10.4257/oeco.2007.1103.09.

AUGUSTO, R.C., MAGALHÃES, A.C.S. and MELLO-SILVA, C.C., 2012. The influence of population density and food intake on the reproductive biology of Biomphalaria glabrata (Mollusca) and calcium proportion in snails experimentally infected with Schistosoma mansoni (Trematoda). Revista de Patologia Tropical, vol. 41 , pp. 83-92.

BAILEY, E. and HORNE, J.A., 1972. The role of ketone bodies in the adult desert locust. The Biochemical Journal, vol. 128, no. 3, pp. 79. http://dx.doi.org/10.1042/bj1280079Pa. PMid:4634844.

BARBOSA, F.S. and BARBOSA, S.C., 1994. The bioecology of snails vectors for Schistosomiasis in Brazil. Cadernos de Saude Publica, vol. 10, no. 2, pp. 200-209. http://dx.doi.org/10.1590/ S0102-311X1994000200007. PMid:14762561.

BECKER, W., 1980. Metabolic interrelation ships of parasitic trematodes and mollusks, especially Schistosoma mansoni in Biomphalaria glabrata. Zeitscherift für Parasitenkunden, vol. 63, pp. 101-111.

BEZERRA, J.C.B., BECKER, W. and ZELCK, U.E., 1997. A comparative study of the organic acid content of the hemolymph of Schistosoma mansoni: resistant and susceptible strains of Biomphalaria glabrata. Memorias do Instituto Oswaldo Cruz, vol. 92, no. 3, pp. 421-425. http://dx.doi.org/10.1590/S007402761997000300021. PMid:9332612.

BEZERRA, J.C.B., KEMPER, A. and BECKER, W., 1999. Profile of organic acid concentrations in the digestive gland and hemolymph of Biomphalaria glabrata under estivation. Memorias do Instituto Oswaldo Cruz, vol. 94, no. 6, pp. 779-784. http:// dx.doi.org/10.1590/S0074-02761999000600012. PMid:10585654.

BIELEFELD, U., ZIEROLD, K., KÖRTJE, K.H. and BECKER, W., 1992. Calcium localization in the shell-forming tissue of the freshwater snail, Biomphalaria glabrata: a comparative study of various methods for localizing calcium. The Histochemical Journal, vol. 24, no. 12, pp. 927-938. http://dx.doi.org/10.1007/ BF01046498. PMid:1283386.

CANTINHA, R.S., BORRELY, S.I., NAKANO, E., AMARAL, A., SILVA, L.R.S. and MELO, A.M.M.A., 2010. Effects of high dose rate gamma radiation on survival and reproduction of Biomphalaria glabrata. International Journal of Low Radiation, vol. 7, no. 4, pp. 245-252. http://dx.doi.org/10.1504/IJLR.2010.034912.

CARVALHO, O.S., ROCHA, R.S., MASSARA, C.L. and KATZ, N., 1988. Primeiros casos autóctones de esquistossomose mansonica em região do noroeste do Estado de Minas Gerais (Brasil). Revista de Saude Publica, vol. 22, no. 3, pp. 237-239. http:// dx.doi.org/10.1590/S0034-89101988000300011. PMid:3148189.

DAVIES, T.W. and ERASMUS, D.A., 1984. An ultrastructural study of the effect of parasitism by larval Schistosoma mansoni on the calcium reserves of host, Biomphalaria glabrata. Cell and Tissue Research, vol. 236, no. 3, pp. 643-649. http://dx.doi. org/10.1007/BF00217234. PMid:6467339.

EBANKS, S.C., O'DONNELL, M.J. and GROSELL, M., 2010. Characterization of mechanisms for $\mathrm{Ca}^{2+}$ and $\mathrm{HCO}_{3}{ }_{3} / \mathrm{CO}_{3}{ }^{2-}$ acquisition for Shell formation in embryos of the freshwater common pond snail Lymnaea stagnalis. The Journal of Experimental Biology, vol. 213, no. Pt 23, pp. 4092-4098. http://dx.doi.org/10.1242/ jeb.045088. PMid:21075951.

GUERINO, L.R., LINHARES, A.X., MAGALHÃES, L.A. and ZANOTTI-MAGALHÃES, E.M., 2009. Attraction of Schistosoma mansoni Sambon, 1907 miracidia to Biomphalaria glabrata (Say, 1818) in the presence of Angiostrongylus costaricensis Morera and Céspedes, 1971 infection. Brazilian Journal of Biology = Revista Brasileira de Biologia, vol. 69, no. 4, pp. 1105-1105. http:// dx.doi.org/10.1590/S1519-69842009000500013. PMid:19967180.

HOCHACHKA, P.V., 1983. The mollusca. New York: Academic Press, pp. 254-261.

LEWIS, B.R., JUTTNER, I., REYNOLDS, B. and ORMEROD, S.J., 2007. Comparative assessment of stream acidity using diatoms and macroinvertebrates: implications for river management and conservation. Aquatic Conservation: Marine and Freshwater Ecosystems, vol. 17, no. 5, pp. 502-519. http://dx.doi.org/10.1002/ aqc.787.

MAGALHÃES, A.C.S., PINHEIRO, J. and MELLO-SILVA, C.C., 2011a. A mobilização do cálcio em Biomphalaria glabrata exposta a diferentes quantidades de carbonato de cálcio. Revista de Patologia Tropical, vol. 40, no. 1, pp. 46-55. http://dx.doi. org/10.5216/rpt.v40i1.13916.

MARXEN, J.C., NIMTZ, M., BECKER, W. and MANN, K., 2003. The major soluble $19.6 \mathrm{kDa}$ protein of the organic shell matrix of the freshwater snail Biomphalaria glabrata is an N-glycosylated dermatopontin. Biochimica et Biophysica Acta, vol. 1650, no. 1-2, pp. 92-98. http://dx.doi.org/10.1016/S1570-9639(03)00203-6. PMid:12922172.

MELLO-SILVA, C.C., VILAR, M.M., VASCONCELLOS, M.C., PINHEIRO, J. and RODRIGUES, M.L.A., 2010. Carbohydrate metabolism alterations in Biomphalaria glabrata infected with Schistosoma mansoni and exposed to Euphorbia splendens var. hislopii látex. Memorias do Instituto Oswaldo Cruz, vol. 105, no. 4, pp. 492-495. http://dx.doi.org/10.1590/S0074-02762010000400024. PMid:20721497.

MEYER, R., BECKER, W. and KLIMKEWITZ, M., 1986. Investigations of the ketone body metabolism of Biomphalaria glabrata: Influence of starvation and infection with Schistosoma mansoni. Journal of Comparative Physiology, vol. 156B, no. 4, pp. 563-567. http://dx.doi.org/10.1007/BF00691043.

PARAENSE, W.L., 1970. Planorbídeos hospedeiros intermediários do Schistosoma mansoni. In: A.S. CUNHA. Esquistossomose mansoni: por um grupo de colaboradores especializados. São Paulo: Sarvier/Edusp, pp. 13-30. 
ROSAS, E., 1987. Observações ecológicas sobre Biomphalaria straminea (Dunker, 1848) em áreas do nordeste, Brasil. Memorias do Instituto Oswaldo Cruz, vol. 82, pp. 311-314. http://dx.doi. org/10.1590/S0074-02761987000800059.

SCHWARTZ, C.F. and CARTER, C.E., 1982. Properties of glycogen synthase and phosphorylase from Biomphalaria glabrata (mollusca). The Journal of Parasitology, vol. 68, no. 2, pp. 228235. http://dx.doi.org/10.2307/3281180. PMid:6804613.

SILVA, H.K.P., MACEDO, S.J. and BRAYNER, F.M.M., 2010. Avaliação das concentrações de metais traço nos sedimentos do parque dos manguezais, região metropolitana do Recife (Rmr), Pernambuco, Brasil. Tropical Oceanography, vol. 38, pp. 174-180.

SILVA, M.J.M. and BARROS, M., 2001. Occurrence and distribution of fresh-water molluses in the Riacho Fundo Creek Basin, Brasilia, Brazil. Revista de Biologia Tropical, vol. 49, no. 3-4, pp. 865-870. PMid:12189816.

SILVA, P.B., BARBOSA, C.S., PIERI, O., TRAVASSOS, A. and FLORENCIO, L., 2006. Aspectosfísico-químicos e biológicos relacionados à ocorrência de Biomphalaria glabrata em focos litorâneos da esquistossomose em Pernambuco. Quimica Nova, vol. 29, no. 5, pp. 901-906. http://dx.doi.org/10.1590/S010040422006000500003 .

SMINIA, T., DE WITT, N.D., BOS, J.L., VAN NIEUWMEGEN, M.E., WITTER, M.P. and WONDERGEM, J., 1980. Structure and function of the calcium cells of freshwater pulmonate snail Lymnaea stagnalis. Netherlands Journal of Zoology, vol. 27, no. 2, pp. 195-208. http://dx.doi.org/10.1163/002829677X00036.

STANISLAWSKI, E. and BECKER, W., 1979. Influences of semi-synthetic diets, starvation and infection with Schistosoma mansoni (trematoda) on the metabolism of Biomphalaria glabrata (Gastropoda). Comparative Biochemistry and Physiology, vol. 63, no. 4, pp. 527-533. http://dx.doi.org/10.1016/0300-9629(79)90189-0.
TIELENS, A.G.M., 1994. Energy generation in parasitic helminths. Parasitology Today (Personal Ed.), vol. 10, no. 9, pp. 346-352. http://dx.doi.org/10.1016/0169-4758(94)90245-3. PMid:15275412.

TUNHOLI, V.M., LUSTRINO, D., TUNHOLI-ALVES, V.M., GARCIA, J.S., MELLO-SILVA, C.C., MALDONADO JUNIOR, J.R.A., RODRIGUES, M. and PINHEIRO, J., 2011. Influence of Echinostoma paraensei (Lie and Basch, 1967) infection on the calcium content in Biomphalaria glabrata (Say, 1818). Experimental Parasitology, vol. 129, no. 3, pp. 266-269. http:// dx.doi.org/10.1016/j.exppara.2011.07.016. PMid:21820434.

TUNHOLI, V.M., TUNHOLI-ALVES, V.M., LUSTRINO, D., ROSANE, N., CASTRO, R.N., SANT'ANA, L.O., GARCIA, J.S., ARNALDO, M.A.J., SANTOS, M.A.J., RODRIGUES, M.L.A. and PINHEIRO, J., 2013. Aerobic to anaerobic transition in Biomphalaria glabrata (Say, 1818) infected with different miracidial doses of Echinostoma paraensei (Lie and Basch, 1967) by high-performance liquid chromatography. Experimental Parasitology, vol. 133, no. 4, pp. 403-410. http://dx.doi.org/10.1016/j. exppara.2013.01.012. PMid:23376444.

TUNHOLI-ALVES, V.M., TUNHOLI, V.M., GARCIA, J.S., COSTA-NETO, S.F., MALDONADO-JÚNIOR, A., SANTOS, M.A.J., THIENGO, S.C. and PINHEIRO, J., 2012. Changes in the calcium metabolism of Biomphalaria glabrata experimentally infected with Angiostrongylus cantonensis. Journal of Helminthology, vol. 88, no. 2, pp. 1-6. http://dx.doi.org/10.1017/S0022149X12000867. PMid:23290340.

ZELCK, U.E., BECKER, W. and BAYNE, C.J., 1995. The plasma proteins of Biomphalaria glabrata in the presence and absence of Schistosoma mansoni. Developmental and Comparative Immunology, vol. 19, no. 3, pp. 181-194. http://dx.doi.org/10.1016/0145305X(95)00012-I. PMid:8595817. 